\title{
Development of Android-Based IPMLM with Scaffolding Learning Approach in Newton's Law of Motion Material to Increase HOTS
}

\author{
T.K. Ardiyati ${ }^{*}$, Suparno ${ }^{2}$, E. Eveline ${ }^{3}$, B.E. Dasilva ${ }^{4}$ \\ 1,2,3,4 Graduate School, Physics Education Department, Yogyakarta State University, Yogyakarta, Indonesia \\ e-mail: tiaraatxiaomi@gmail.com,suparnomipa@uny.ac.id,erlin.eve1@gmail.com, beatrix.elvi@gmail.com
}

\begin{abstract}
Combination of Android-based IPMLM and scaffolding acts as a synergism that increase students' actual abilities towards their potential abilities (ZPD). Thus, it can bridge students to achieve HOTS. This study aimed to: a) produce an Android-based IPMLM with scaffolding learning approach in Newton's law of motion material that is feasible to apply to increase high school students' HOTS; b) examine the effectiveness of android-based IPMLM with scaffolding learning approach in Newton's law of motion material in increasing high school students' HOTS. This R\&D used the 4-D model consisted of defining, designing, developing, and disseminating stages. Empirical test subjects of HOTS items were students of class XI MIPA, subjects of IPMLM readability test and extensive trial were students of class X MIPA. The extensive trial took two classes in each school, namely experimental and control class. Data collected through questionnaires and tests. Data analysis techniques included calculation of average scores, Aiken's validity index, item fit MNSQ INFIT-OUTFIT parameters, item reliability, and Anova mixed design test. The results showed that: 1) the developed Android-based IPMLM is feasible to be used in learning with scaffolding approach in Newton's law of motion material to increase high school students' HOTS; 2) The increase of HOTS in the experimental class is greater than the control class. Hence, an Android-based IPMLM with scaffolding learning approach is effective to increase high school students' HOTS, especially in Newton's law of motion material.
\end{abstract}

Keywords: Android-Based IPMLM, Scaffolding Approach, HOTS, Newton's Law of Motion

\section{Introduction}

Mastery of HOTS has an impact on students' ability to face the challenges and intense global competition (Direktorat Pembinaan Sekolah Menengah Atas, 2017; Jensen et al., 2014). Study showed that learning which includes higher order thinking skills tests can boost students to obtain their deep understanding and also get better memory of the core facts (Jensen et al., 2014). Problem-based learning oriented to higher-order thinking will promote student's ability to think hard. In addition, high level problems can also encourage students' collaboration skills such as discussion and communication (Nofrion \& Wijayanto, 2018). Consequently, HOTS becomes an important thing that needs to be enhanced in learning, including in Physics subjects (Pratama \& Istiyono, 2015).

Physics as an important subject taught in high school, contains various concepts and principles that are usually abstract. Physics also requires students to be able to make more complex conclusions and solve physics problems. It is important for students to be able to identify and interpret physics concepts and principles when learning them (Mundilarto, 2002). Physics as part of science prepares students to have scientific literacy skills that focus on the use of physics concepts correctly, thinking critically, explaining physics phenomena, and drawing conclusions based on experiments (OECD, 2013; Toharudin et al., 2011). Thus, the characteristics of higher order thinking skills that include critical thinking, creative thinking, problem solving, are in line with the essence of Physics itself.

Previous studies showed that in fact, the achievement of HOTS in Indonesia have not been comprehensive. The 10th-grade students' Physics HOTS in Bantul is still mostly at the low and medium category (Istiyono, 2017). In line with this, there are $3.53 \%$ of students who are able to achieve HOTS level of evaluating, and none of them can accomplish HOTS level of creating in senior high schools in Jayapura City (Budiarti et al., 2017). Research conducted

\footnotetext{
${ }^{\star}$ Corresponding author.

Received 11 September 2019; Accepted 4 August 2020; Available online 1 September 2020 (C) 2020 JPI. All Rights Reserved
} 
by Kurniati et al. (2016) state that 18 of 30 junior high school students spread across Jember regency has medium-level HOTS. Meanwhile, the others are still unable to solve the HOTS problems. The results of the assessment of students' HOTS in Jember in other studies revealed that some of them still have difficulty in mastering problem solving aspect and are not able to explain their arguments scientifically in the reasoning aspect (Supeno et al., 2019). Another study showed that there are misconceptions in Physics especially material Newton's law of motion, and specifically in analyzing the forces acting upon objects on inclined planes (Kurniawan \& Arief, 2015). When solving the problem of Newton's law of motion, student must be good at describing the forces involved and understanding its relevance to everyday phenomena. This activity certainly involves analyzing and evaluating in HOTS. Thus, this research and development took material Newton's law of motion.

The evidence that have been described above show that the mastery of students' HOTS still needs to be improved. It is needed an innovation in physics learning which focus on increasing students' HOTS. One step that can be done is the use of mobile technology as a learning media. It incidentally coincides with learning in the 21 st century that prepares future generations with the advancement of information and communication technology (Ariana et al., 2020; Rahayu et al., 2019). Technology integration in learning can have an impact on enhancing student performance both on basic and advanced physics concepts (Wang et al., 2015). The use of mobile technology in the form of personal, wireless, and handheld devices allows students as users to access information and learning materials anytime and anywhere, so they do not have to wait for a particular time to learn (Ally, 2009). Mobile technology is proven to be able to improve critical thinking skills and higher-order thinking skills (Agustihana \& Suparno, 2018; Putra \& Sudarti, 2015). Mobile technology also enables interactive learning which supposes students to practice their skills and receive feedback (Ciampa \& Gallagher, 2013). Interactive teaching material is interpreted as a combination of media in the form of text, audio, images, and video that can be operated and allows user interaction (Prastowo, 2014). Technology-based learning media can display many physics processes and phenomena clearly (Jian-hua \& Hong, 2012). Students are given the opportunity to be familiar with physics phenomena and objects and also the chance to propose hypotheses (Chen et al., 2012). Therefore, the technology-based learning media has an impact on raising problemsolving skills in Physics (Wartono et al., 2018). Based on the characteristic mentioned, mobile technology can refer to Android-based devices.

Android-based application (PML) developed by Mardiana and Kuswanto (2017) is able to facilitate the level of thinking from simple to more complicated thinking. It happens because the use of PML can present abstract material to be more concrete. Multimedia learning modules that are compatible with Android-based smartphone can ease conceptual understanding of physics and affect problem-solving ability (Darma et al., 2019). The utilization of Android-based devices as learning media can also be actualized in the form of a virtual laboratory application. Through this media, virtual material and practicums are presented attractively using animation and simulation. Students are supported to build conceptual understanding and conduct learning activities independently (Arista \& Kuswanto, 2018). Referring to the results of these studies, it can be said that mobile learning media particularly Android-based device is very useful in physics learning, especially to enhance higher order thinking skills.

The implementation of technology-based media in learning will be more optimal if supported by the appropriate approach, such as scaffolding. The combination of human assistance and technology-based learning tools acts as a synergistic scaffolding system. The combination is appropriate to support learning in complex situations, including science that contains many abstract concepts (Lin et al., 2012). The scaffolding approach combined with technology-based interactive media such as PhET influence both the achievement of learning independence (Eveline et al., 2019) and science process skills (Ardiyati et al., 2019).

Learning using scaffolding approach means the teacher provides scaffold or assistance through which students can increase their actual abilities to their potential abilities (Schunk, 2012; Woolfolk, 2009). The assistance is given in the early stages of learning which is gradually reduced until students can finally learn and complete the task independently (Slavin, 2011). 
Scaffolding supports constructivist learning which is the theoretical foundation for physics learning. This theory believes that learning process is the result of the construction of knowledge in students independently through thinking activities. This kind of paradigm will have an impact on cognitive sharpening as well as development of mindset and student skills. Accordingly, it can bridge the achievement of higher order thinking skills. Someone who has reached the age of 11 years, in which high school students have been already at this age, is said to have been able to think abstractly and scientifically (Daryanto, 2016; Suparno, 2013; Woolfolk, 2009). Vygotsky's constructivist theory implies the concept of zone of proximal development (ZPD). ZPD is the threshold area of a child's ability to solve certain problems (Woolfolk, 2009). He will be able to deal with these problems if he gets help from adults or collaborates with peers who have more competence than himself (Slavin, 2011). Right at this point, assistance in scaffolding is given and increasingly reduced until students can complete assignments independently (Schunk, 2012).

The implementation of scaffolding in this study is positioned as a learning approach. Learning approach is interpreted as a reference in order to attain the desired learning targets in the form of learning procedures that are still theoretical (Hamid, 2011). The implementation of scaffolding approach in this study refers to Anghileri (2006) which divides into three levels of learning and each level is divided into interactions. The first level is environmental provision which means providing a learning environment, including the formation of student groups. The second level is explaining, reviewing, and restructuring where there is a direct interaction between the teacher and students regarding the topic being discussed. The last level is developing conceptual thinking in which teachers and students have the opportunity to express shared understanding.

Based on the description above, it can be interesting to develop Android-based mobile application as learning media and combine it with scaffolding learning approach. Hence, this study aimed to develop Android-based Interactive Physics Mobile Learning Media (IPMLM) with scaffolding learning approach in Newton's law of motion material to increase high school students' HOTS. Referring to the Indonesian National Qualification Framework, learning achievement in the aspect of knowledge by high school graduates is to have basic operational and factual knowledge of specific work fields. High school graduates are expected to have the ability to select the right solution in problem solving. Therefore, this study focused on level of analyzing (C4) and evaluating (C5).

\section{Method}

This research and development (R\&D) used the 4-D model. The 4-D model consists of defining, designing, developing, and disseminating (Thiagarajan et al., 1974). The defining stage aimed to establish instructional requirements. This stage includes front-end analysis, learner analysis, task analysis, concept analysis, and specifying instructional objectives. The front-end analysis was gathering information through literature review and field studies in high school. The learner analysis was done by observing learning. The main points observed were academic capabilities, attitude and behavior, learning motivation, and level of student development. The task analysis can be referred to curriculum analysis (identification of $\mathrm{KI}$ and KD). The concept analysis was identifying parts of material which to be included into IPMLM application. This analysis consisted of analyzing material facts, concepts, laws, theories, and procedures. Meanwhile, the activity done in the specifying instructional objectives was determining learning objectives.

The designing stage was intended to design the initial draft of lesson plan (RPP), instrument for measuring HOTS, and IPMLM application. This stage generated flowcharts and storyboards of IPMLM. Flowchart shows navigation plots when operating IPMLM. Storyboard contains a display of application content along with its description that explains IPMLM's components that appears on the screen of an android smartphone. The developing stage aimed at modifying and developing the initial draft as well as evaluating the feasibility and validity of the product, which resulted in a revised product $I$. This stage also aimed to conduct a limited trial that produced a revised product II and an extensive trial that produced a revised 
product III. Disseminating stage had a goal to disseminate the product. This stage was done by publication in scientific journal and conference proceeding.

The subjects of empirical test of HOTS measurement instrument consisted of 344 students of class XI MIPA in Sleman regency, namely SMAN 1 Pakem, SMAN 1 Ngaglik, SMAN 2 Sleman, SMAN 1 Turi, and SMAN 1 Godean. The subjects of IPMLM readability test were 30 students of class $X$ in SMA N 1 Godean. The subjects of extensive trial were students of class X MIPA in MAN 3 Sleman, SMAN 2 Sleman, and SMAN 1 Pakem. Each school was taken two classes, namely the experimental class and the control class. The study was conducted in January to March 2019.

The lesson plan products, HOTS measurement instrument, and IPMLM application were assessed for feasibility before being used in limited trial. The feasibility of the lesson plan was assessed by three raters. The content validation of HOTS items was performed by seven raters. Meanwhile, the IPMLM's feasibility assessment was carried out by media and material expert. The results of the feasibility assessment were used to calculate the average final score which was then given the criteria referring to the ideal assessment criteria (Sudijono, 2009).

The limited trial consisted of an empirical test of HOTS measurement instrument and an IPMLM readability test. The empirical validity of HOTS items was known from the fitness of items with the PCM 1-PL model. The parameters used were INFIT MNSQ and OUTFIT MNSQ. The range of received MNSQ INFIT values is 0.77-1.30. Meanwhile, the MNSQ OUTFIT limit received is 0.5-1.5 (Boone et al., 2014). Reliability estimates were known through item estimates. The criteria are weak $(<0.67)$, sufficient $(0.67-0.80)$, good $(0.81-0.90)$, very good (0.91-0.94), and special (>0.94). Data analysis of empirical test was also carried out to find the information function and the standard error measurement (SEM). Both display the contribution of test items in revealing the abilities measured in the test along with their standard measurement errors (Hambleton et al., 1991).

The results of the IPMLM readability test on a limited test and the student response questionnaire on an extensive trial were analyzed with steps such as the product feasibility analysis. Meanwhile, effectiveness test of the learning using android-based IPMLM with scaffolding approach was done through Anova mixed design analysis using HOTS pretestposttest score data.

\section{Result and Discussion}

Data analysis of empirical test of HOTS measurement instrument resulted the MNSQ INFIT and MNSQ OUTFIT values for each item that were between 0.97-1.09 with an average of 1.01. They showed that all HOTS items developed were fit with 1-PL PCM models, which means they were empirically valid. The obtained value of item estimation was 0.80 , which means the reliability of HOTS items was sufficient. The information function and SEM are presented in Figure 1.

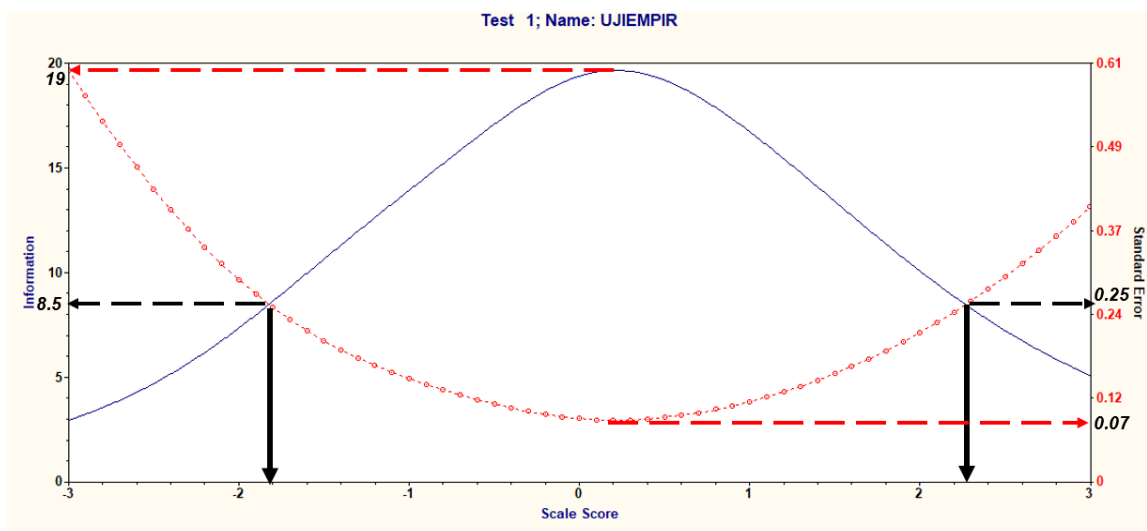

Figure 1. Test Information and SEM Curve 
The intersection of the information function and SEM curves shows a picture of students' abilities that can be measured by HOTS measurement instrument in empirical tests. HOTS questions could measure students' abilities in the range -1.8 to 2.25. Through the intersection, it is also known that the value of the HOTS information function was 8.5 and SEM was 0.25 .

The Android-based IPMLM application that was developed initially consisted of six main menus, namely the User's Guide, Competency, Material, Student Worksheet, Evaluation, and Developer Profile. The Discussion Forum menu was further added base on the media expert's advice. The material menu was equipped with pictures, videos, practice questions with clues to answer. The LKS menu contains instructions of experiment and was equipped with a button to upload the results of the discussion. The evaluation menu contains HOTS items that have been validated. Students can access test scores right after they finish the test. The feasibility of IPMLM by media experts was stated to be very good in the aspects of software engineering, ease and flexibility in accessing, and visual communication, and stated as good in both of the aspects of presentation and interactivity. The average score of media experts was 3.23 and included in good categories. Suggestions for improvement from media experts was to change the appearance of the material part of the scroll form into a pointer form as in the power point display and add a discussion forum menu. The feasibility of IPMLM by material experts was stated to be very good in both aspects, namely learning and material, with an average value of 3.74 (very good). Figures below show examples of the display of Android-based IPMLM application. Figure 3 indicates main menus in Android-based IPMLM that consist of user guideline, information about competencies achieved, subject material, student worksheet, evaluation for student examination, developer profile, and discussion forum. Figure 2 presents a preview of material display. Figure 3 shows a preview of video in Material menu.

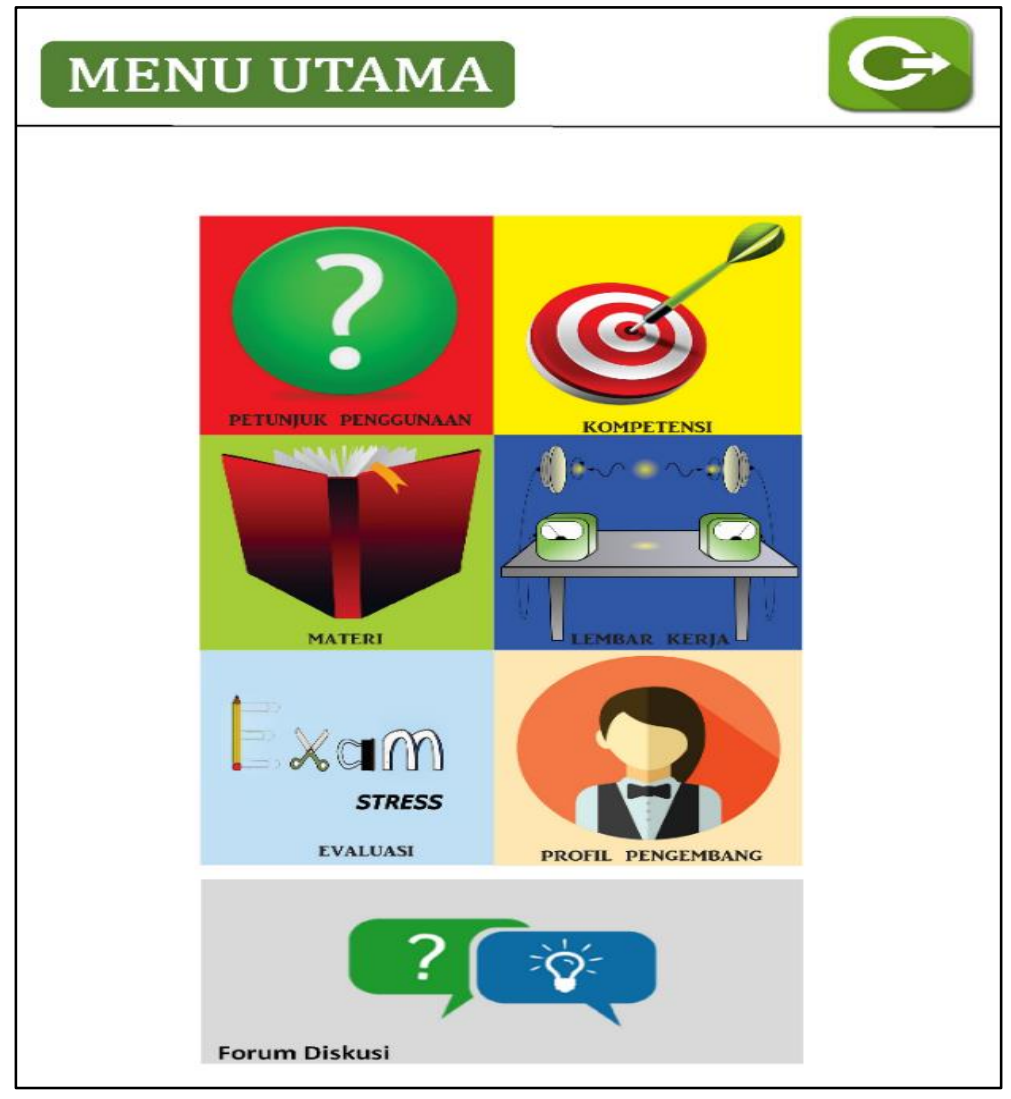

Figure 2. Main menu 


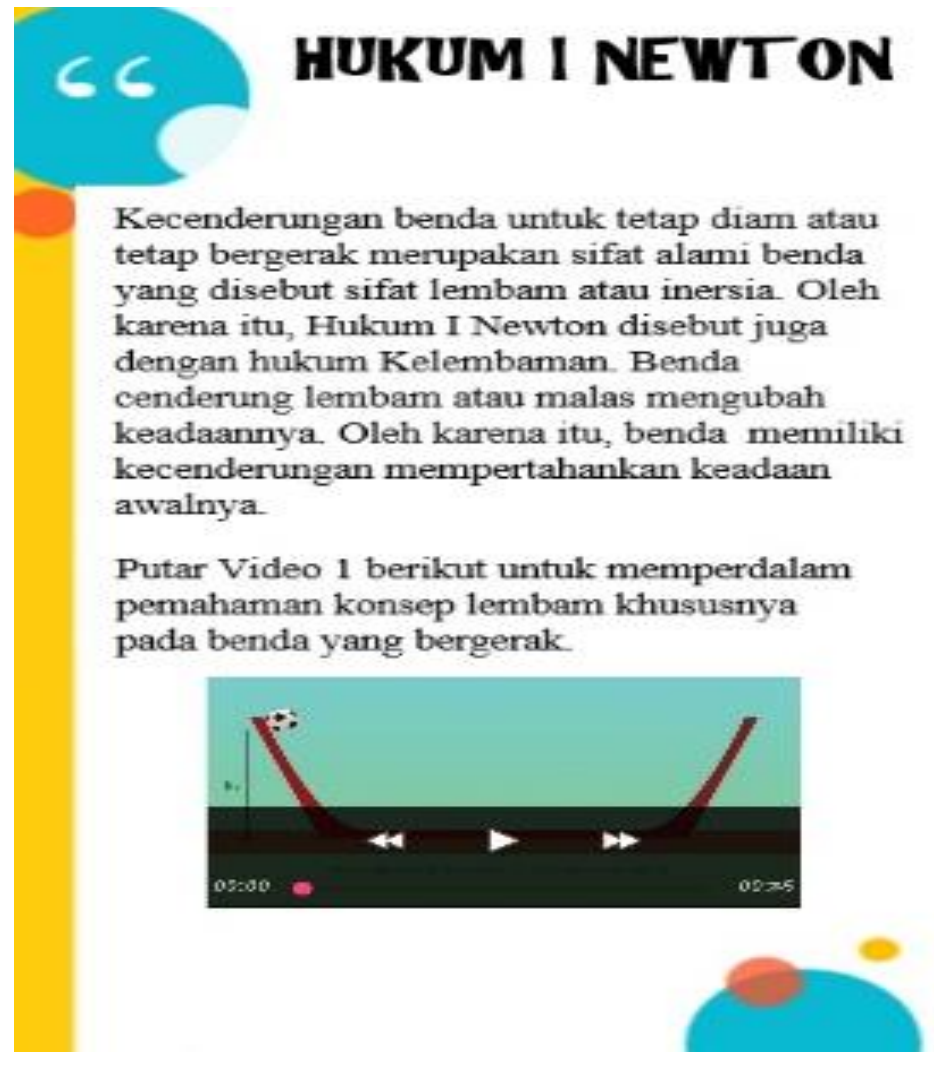

Figure 3. Material menu

The readability test results showed that IPMLM was very good in terms of content, graphics, and language. Meanwhile, in terms of presentation, IPMLM was in the good category. Suggestions from students were to add animation to the material menu and change the image icon of the IPMLM application to be more interesting. The results of students' responses to IPMLM taken at the end of the meeting in a extensive trial showed very good categories in all aspects, both content, presentation, graphics, and language. Meanwhile, the results of students' responses to their learning activities were very good in all aspects, namely aspects of the implementing lesson plans, applying psychomotor, and applying HOTS.

The main data of this study is the pretest-posttest score of HOTS. The analysis aimed to determine the effectiveness of the implemetation of learning using Android-based IPMLM with a scaffolding approach.

Furthermore, the difference between the experimental class and the control class could be known by looking at the mean difference value. Table 1 presents Pairwise Comparison which shows the value of changes experienced by both classes.

Tabel 1. Pairwise Comparisons

\begin{tabular}{lccccc}
\hline \multicolumn{1}{c}{ Group } & (I) TIME & (J) TIME & Mean Difference (I-J) & Std. Error & Sig \\
\hline Experiment & pretest & posttest & 38.337 & .415 & .000 \\
Control & pretest & posttest & 15.405 & .412 & .000 \\
\hline
\end{tabular}

Table 6 shows that the significance of both classes was $<0.05$. This means that there was a significant difference in the increase of HOTS in the experimental class and the control class. Improvement in the experimental class was greater than the control class based on the mean difference. The mean difference was obtained from the posttest average minus the pretest average. The difference in the increase of HOTS between the experimental class and the control class visually is shown by Figure 4. 


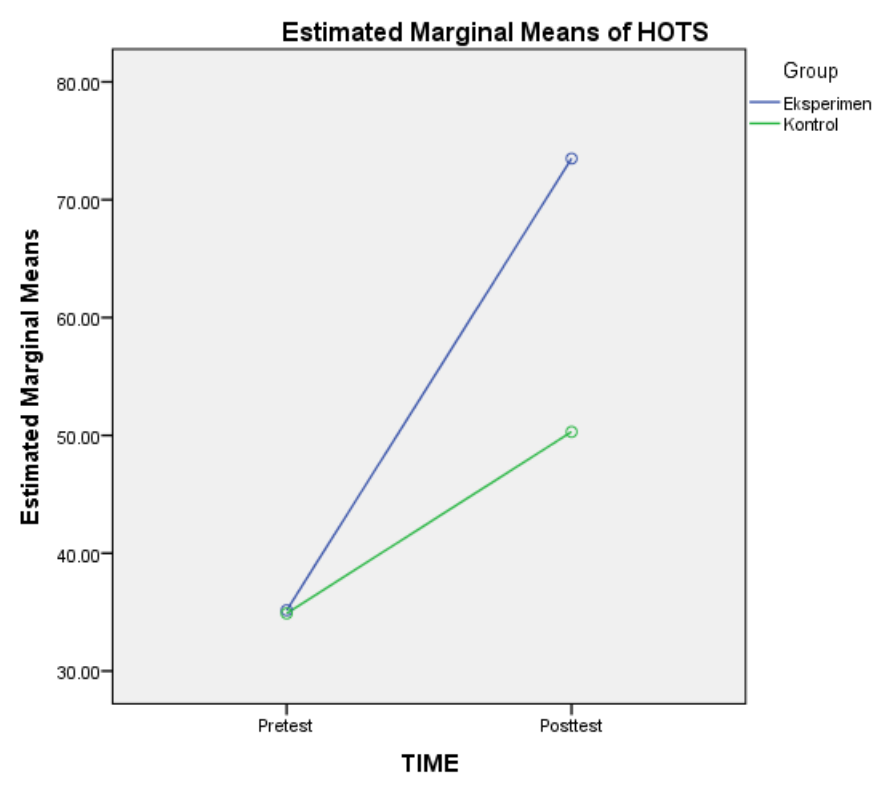

Figure 4. Graph of HOTS Improvement

Visually, there is a different slope between experimental class and control class. The graph shows that the increase of HOTS in the experimental class was greater than the control class. Therefore, an Android-based IPMLM with a scaffolding learning approach was effective to be implemented to increase students' physics higher order thinking skills, especially in Newton's law of motion material. The use of mobile technology as a learning media such as Android-based IPMLM supported by assistance in the scaffolding approach can facilitate meaningful physics learning for students. Furthermore, meaningful learning has a role in encouraging the achievement of the required skills from a learning process, in this context is HOTS. It is corresponding to Lin et al. (2012) that the combination of technology-based learning tools and human help can work together in facilitating complex science learning.

The materials in Android-based IPMLM are presented as attractive as possible in order that student can stay focused on learning (Attewell, 2005; Prastowo, 2014). The display on the Material menu is in the form of a slide show containing text, images, and equipped with animated video. The combination of them in a user friendly system acts as an interactive media which is capable of being a good environment and learning material (Anitah, 2008; Prastowo, 2014). It gives a stimulating new experience for students, so it will ease them to understand (Wati, 2016) concepts in a physics phenomenon. Through various forms of presentation of material in the Android-based IPMLM, students are given the opportunity to be familiar with physics phenomena and objects, and also allowed the chance to propose hypotheses (Chen et al., 2012). The Material menu is equipped with exercises that are accompanied by clues to answer in the form of structured questions that sharpen student's level of analyzing (C4). The materials are arranged in such a way that students can easily access and find the sections of material needed. For example, when the students want to interpret and compare the results of experiments with theories in the Material menu, which hone student's level of evaluating (C5). As expressed by Wati (2016), students who understand the learning material will be able to communicate the material in their own words and expressions.

Android-based IPMLM as a technology-based interactive learning media enables the display of simulations video of physics phenomena that cannot be visible to the naked eye and present abstract physics concepts concretely and more clearly (Anitah, 2008; Jian-hua \& Hong, 2012; Kim \& Hannafin, 2011; Mundilarto, 2002). One of video in Material menu is simulation about phenomena of appearance of static and kinetic friction. The direction of the frictional force on objects that are starting to be pulled up to move can be described more specifically and clearly. Information about the process that occurs in it is also included to support the explanation. Srisawasdi and Sornkhatha (2014) said that visualizations of forces and challenges students' beliefs concerning the phenomenon of the Newton's laws of motion 
are adequate to assist students fix while develop their scientific conceptual understanding. It is effective in reinforcing material memories, helping practicing reasoning, and increasing motivation. Therefore, it can guide their cognitive skills and hone their higher order thinking skills (Agustihana \& Suparno, 2018; Made Rajendra \& Made Sudana, 2018). Simulations video and images are also used as a medium to do apperceptions and present simple experiment instructions to furnish a clearer image of the steps of experiment in Student Worksheet menu.

The character of interactive of Android-based IPMLM allows students to give active responses and get feedback (Anitah, 2008). For instance, the animated video is equipped with play/pause button and time bar. It eases users to set animation playback and repeat the physics process described as they will. Another active responses and feedback such as discussion results upload facility, discussion forum menu to discuss material that is not yet understood, and HOTS test scores access. Those can be a self-evaluation for students as well as facilitate teachers in controlling the success of the learning process immediately (Zainiyati, 2017). The character of mobile of Android-based IPMLM allows more optimal learning in a limited time because it can be accessed anywhere and anytime (Ally, 2009; Zainiyati, 2017).

The improvement of HOTS is also supported by the implementation of scaffolding as a learning approach. As expressed by Kim and Hannafin (2011), the implementation of scaffolding in classroom learning needs to involve teacher, peers, and technology. Yin et al. (2013) prove that the use of scaffolding strategies in participatory simulation in mobile device helps students deepen understanding of complex concepts. The learning system gives students an opportunity to actively participate in learning abstract concepts, and also increase their motivation and collaborative skills.

The scaffolding learning approach in this research and development underlies learning activities and listed in the lesson plan. The application of assistances in the scaffolding approach is divided into three levels, namely environmental provision; explaining, reviewing, restructuring; and developing conceptual thinking (Anghileri, 2006). Each level is broken down into interactions as well as a reference for each learning activity and experiment. The use of Android-based IPMLM is certainly included in these activities. In addition to being emphasized through teacher's supports, the concept of scaffolding itself is also implicit in the Android-based IPMLM application especially the Material and Student Worksheet menu. Images, videos, clue of practice questions, as well as questions that lead students to conclusions or answers to problems can be a help for students.

Students are given help by the teacher starting from the initial stages of learning. It encourages students' activeness and curiosity when they try to understand and solve physics problems (Amanah et al., 2017). For example, at the level of environmental provision, students are given apperception related to physics phenomena in everyday life that are presented by IPMLM. The phenomenon presented at the apperception is then used in the closing activities to be linked to the conclusion of the results of experiment. These activities hone the students' ability to analyze (C4). Assistance in scaffolding also aims to facilitate the construction of students' knowledge processes through thinking activities and converting raw information into their own statements (Ertikanto, 2016; Suparno, 2013). For instance, at the level of reviewing and on the prompting and probing interaction, the teacher provides questions that lead students to the solution. Afterwards, the teacher re-expresses and expands the answers raised by students (interpreting student's actions and talk interaction).

The frequency of assistance is gradually reduced (Slavin, 2011) refers to Anghileri (2006). It aims to promote students to keep trying to solve problems and be brought towards their potential abilities (Schunk, 2012; Woolfolk, 2009). In other words, it sharpens cognitive abilities and boosts the development of students' thinking skills, by permitting students to learn independently systematically. Students can acquire physics concepts independently, so they reach higher order thinking skills and have a positive impact on improving learning outcomes (Daryanto, 2016; Nur Aini et al., 2015). For example, on the rephrasing students' talk interaction (level of restructuring) at the first meeting, the teacher highlights the result of Newton's first law of motion experiment obtained by students and re-express the statement of Newton's first law. It proposes to attract students' attention and accuracy on checking the suitability of the results of the experiment as they should be. Thereafter, at the second meeting, 
the teacher encourages students to check the results of their experiments. Students try to compare the data of Newton's third law experiments obtained to the theory in the material. This action stimulates the ability to analyze (C4) and evaluate (C5). Another example, on making connections interaction at the level of developing conceptual thinking, the teacher still gives direction to students to connect the conclusions of the experimental results to other phenomena that are still related to the material at the first meeting. Meanwhile, at the third meeting, students must be able to connect the conclusion of the experiment to other phenomena without relief. This activity motivates students to attain the ability to analyze (C4) and create (C6).

Furthermore, the results were given more detail by calculating the percentage of categories based on the number of students who reach that category. Students' HOTS performance at the posttest on the level of analyzing (C4) in the experimental and control class are shown in Figure 5.

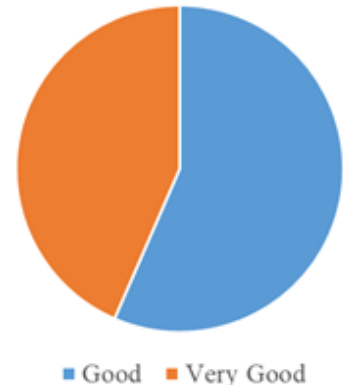

(a)

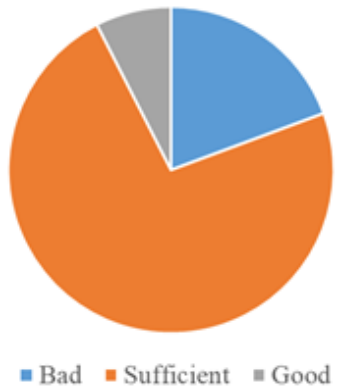

(b)

Figure 5. The Percentage of Categories of Students' HOTS Performance at the Posttest on the Level of Analyzing in Experimental (a) and Control Class (b)

Figure 6 shows that $56.52 \%$ of students reached the good category and $43.48 \%$ of students reached the very good category in the experimental class on the level of analyzing (C4). Meanwhile, the achievements of the level of analyzing (C4) in the control class varied from bad, sufficient, to good categories, namely $19.35 \%, 73.12 \%$, and $7.53 \%$ respectively. The percentage of categories of results of HOTS posttest on the level of evaluating (C5) is shown in Figure 8.

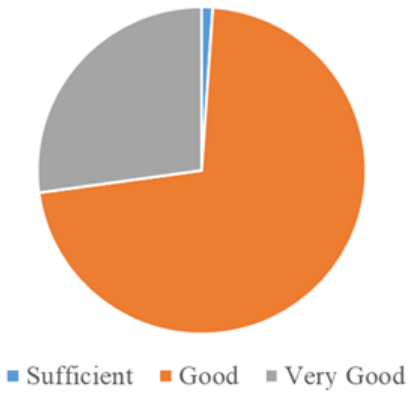

(a)

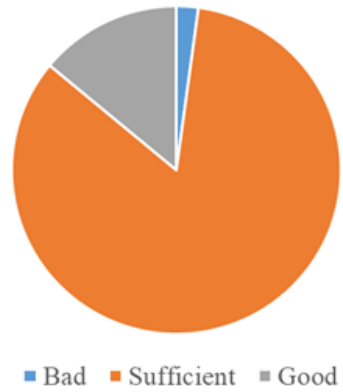

(b)

Figure 6. The Percentage of Categories of Students' HOTS Performance at the Posttest on the Level of Evaluating in Experimental (a) and Control Class (b)

Figure 6 shows that there were $1.09 \%$ of students categorized as sufficient, $71.74 \%$ of students categorized as good, and $27.17 \%$ of students categorized as very good in the experimental class on the level of evaluating (C5). Meanwhile, the performances of the level of evaluating (C5) in the control class were $2.15 \%$ of students were the in bad category, $83.87 \%$ of students were in the sufficient category, and $13.98 \%$ of students were in the good category. The results are known that the performances of the level of analyzing and evaluating 
in each experimental class are better than the control class. It was further known that the achievement of the level of analyzing category is better than the level of evaluating category in the experimental class. This is caused by the hierarchical relationship between the analyze, evaluate, and create abilities (Kurniati et al., 2016). The evaluating (C5) occupies higher level than analyzing (C4) (Anderson \& Krathwohl, 2010). In line with Istiyono et al. (2014) that aspects of higher order thinking skills have a gradual difficulty from the easiest is analyzing, evaluating, and the most difficult is creating.

The diagram in Figure 6(b) shows that on the level of evaluating (C5), there were students who are in the sufficient category, while other students reached the good and very good categories. It could be caused by the differences of student's abilities in achieving their zone of proximal development. As it is known, scaffolding assistance can act well if students are at the point of readiness to receive certain information or assignments (Morrison, 2012; Slavin, 2011). Hence, more help is needed for these students. In addition, there were found several students who did not focus during the experimental activities and misused the smartphone for other activities unrelated to learning. For example, at rephrasing students' talk interactions, instead of participating in discussion with peer group to compare the experimental data with the theory in the material menu, several students used their smartphone to play games and watch YouTube. It means the students left behind the activity, so there is possibility that their ability to evaluate were not perfectly trained.

Overall, between Android-based Interactive Physics Mobile Learning Media (IPMLM) and scaffolding learning approach are a synergism that is proper to be implemented in learning in order to increase higher-order thinking skills. The result of the development can be used as a more interactive alternative media and approach in physics learning. Other than that, the result of the development can enrich experience through the use of combination of more varied media and approach. The Android-based application and scaffolding approach can certainly be developed in the future on another Physics material. Based on the findings, the use of IPMLM application as learning media needs to give more attention to students to anticipate the misuse of smartphones by students, for example playing game or watching YouTube, especially in discussion activities. The teacher also needs to consider the quality of internet network at school, mainly in doing HOTS test questions in Evaluation menu.

\section{Conclusion}

According to the results and discussion, it can be concluded that Android-based Interactive Physics Mobile Learning Media (IPMLM) and learning tools that are feasible for use in learning with scaffolding approaches to increase high school students' higher order thinking skills (HOTS). Extensive trial results indicate that the change in the pretest to posttest score in the two classes is significantly different, thus the increase of HOTS in the experimental class is greater than the control class. This result shows that the Android-based IPMLM with the scaffolding learning approach effectively increase high school students' higher order thinking skills, especially in Newton's law of motion material.

\section{References}

Agustihana, S., \& Suparno. (2018). Effectiveness of Physics Mobile Learning Media to Improve Higher Order Thinking Skills of Students in Thermodynamics. Journal of Physics: Conference Series, 1097(1). https://doi.org/10.1088/1742-6596/1097/1/012031

Ally, M. (2009). Mobile Learning Transforming the Delivery of Education and Training. Atabasca University Press.

Amanah, P. D., Harjono, A., \& Gunada, I. W. (2017). Kemampuan Pemecahan Masalah dalam Fisika dengan Pembelajaran Generatif Berbantuan Scaffolding dan Advance Organizer. Jurnal Pendidikan Fisika Dan Teknologi, 3(1). https://doi.org/10.29303/jpft.v3i1.334

Anderson, L. W., \& Krathwohl, D. R. (2010). Kerangka Landasan untuk Pembelajaran, Pengajaran, dan Asesmen: Revisi Taksonomi Pendidikan Bloom. Terjemahan Agung 
Prihantoro. Pustaka Pelajar.

Anghileri, J. (2006). Scaffolding Practices that Enhance Mathematics Learning. Journal of Mathematics Teacher Education, 9, 33-52. https://doi.org/10.1007/s10857-006-9005-9

Anitah, S. (2008). Media Pembelajaran. UNS Press.

Ardiyati, T. K., Wilujeng, I., Kuswanto, H., \& Jumadi. (2019). The Effect of Scaffolding Approach Assisted by PhET Simulation on the Achievement of Science Process Skills in Physics. Journal of Physics: Conference Series. https://doi.org/10.1088/17426596/1233/1/012035

Ariana, D., Situmorang, R. P., \& Krave, A. S. (2020). Pengembangan Modul Berbasis Discovery Learning Pada Materi Jaringan Tumbuhan Untuk Meningkatkan Kemampuan Literasi Sains Siswa Kelas Xi Ipa Sma. Jurnal Pendidikan Matematika Dan IPA, 11(1), 34-46. https://doi.org/http://dx.doi.org/10.26418/jpmipa.v11i1.31381

Arista, F. S., \& Kuswanto, H. (2018). Virtual Physics Laboratory Application Based on the Android Smartphone to Improve Learning Independence and Conceptual Understanding. International Journal of Instruction, 11(1), 1-16. https://doi.org/10.12973/iji.2018.1111a

Attewell, J. (2005). Mobile Technologies and Learning. Learning and Skills Development Agency.

Boone, W. J., Staver, J. R., \& Yale, M. S. (2014). Rasch Analysis in the Human Sciences. Springe.

Budiarti, I. S., Suparmi, A., Sarwanto, \& Harjana. (2017). Analyzes of Students' Higher-order Thinking Skills of Heat and Temperature Concept. Journal of Physics: Conference Series. https://doi.org/10.1088/1742-6596/909/1/012055

Chen, S., Lo, H. C., Lin, J. W., Liang, J. C., Chang, H. Y., Hwang, F. K., Chiou, G. L., Wu, Y. T., Lee, S. W. Y., Wu, H. K., Wang, C. Y., \& Tsai, C. C. (2012). Development and Implications of Technology in Reform-based Physics Laboratories. Physical Review Special Topics - Physics Education Research, 8(2), 287-302. https://doi.org/10.1103/PhysRevSTPER.8.020113

Ciampa, K., \& Gallagher, T. L. (2013). Getting in Touch: Use of Mobile Devices in the Elementary Classroom. Computers in the Schools, 30, 309-328. https://doi.org/10.1080/07380569.2013.846716

Darma, R. S., Setyadi, A., Wilujeng, I., Jumadi, \& Kuswanto, H. (2019). Multimedia Learning Module Development based on SIGIL Software in Physics Learning. Journal of Physics: Conference Series. https://doi.org/10.1088/1742-6596/1233/1/012042

Daryanto. (2016). Media Pembelajaran: Perannya Sangat Penting dalam Mencapai Tujuan Pembelajaran. Gava Media.

Direktorat Pembinaan Sekolah Menengah Atas. (2017). Implementasi Pengembangan Kecakapan Abad 21 dalam Perencanaan Pelaksanaan Pembelajaran (RPP). Kementerian Pendidikan dan Kebudayaan.

Ertikanto, C. (2016). Teori Belajar dan Pembelajaran. Media Akademi.

Eveline, E., Jumadi, Wilujeng, I., \& Kuswanto, H. (2019). The Effect of Scaffolding Approach Assisted by PhET Simulation on Students' Conceptual Understanding and Students' Learning Independence in Physics. Journal of Physics: Conference Series. https://doi.org/10.1088/1742-6596/1233/1/012036

Hambleton, R. K., Swaminathan, H., \& Rogers, H. J. (1991). Fundamental of Item Response Theory. Sage Publications, Inc.

Hamid, A. A. (2011). Pembelajaran Fisika di Sekolah: Apa dan Bagaimana Pendekatan Generik Metode Iqra' Dilaksanakan dalam Pembelajaran Fisika. UNY. 
Istiyono, E. (2017). The Analysis of Senior High School Students' Physics HOTS in Bantul District Measured Using PhysReMChoTHOTS. AIP Conference Proceedings. https://doi.org/10.1063/1.4995184

Istiyono, E., Mardapi, D., \& Suparno, S. (2014). Pengembangan Tes Kemampuan Berpikir Tingkat Tinggi Fisika (Pysthots) Peserta Didik Sma. Jurnal Penelitian Dan Evaluasi Pendidikan. https://doi.org/10.21831/pep.v18i1.2120

Jensen, J. L., McDaniel, M. A., Woodard, S. M., \& Kummer, T. A. (2014). Teaching to the Test...or Testing to Teach: Exams Requiring Higher Order Thinking Skills Encourage Greater Conceptual Understanding. Educational Psychology Review, 26(2), 307-329. https://doi.org/10.1007/s10648-013-9248-9

Jian-hua, S., \& Hong, L. (2012). Explore the Effective Use of Multimedia Technology in College Physics Teaching. Energy Procedia, 17, 1897-1900. https://doi.org/10.1016/j.egypro.2012.02.329

Kim, M. C., \& Hannafin, M. J. (2011). Scaffolding Problem Solving in Technology-enhanced Learning Environments (TELEs): Bridging Research and Theory with Practice. Computers and Education, 56(2), 403-417. https://doi.org/10.1016/j.compedu.2010.08.024

Kurniati, D., Harimukti, R., \& Jamil, N. A. (2016). Kemampuan Berpikir Tingkat Tinggi Siswa SMP di Kabupaten Jember dalam Menyelesaikan Soal Berstandar PISA. Jurnal Penelitian Dan Evaluasi Pendidikan, 20(2), 142-155. https://doi.org/10.21831/pep.v20i2.8058

Kurniawan, R., \& Arief, A. (2015). Identifikasi Miskonsepsi Hukum Newton tentang Gerak Bagi Siswa Sekolah Menengah Atas di Kabupaten Nganjuk. Jurnal Inovasi Pendidikan Fisika, 4(2), 1-3. https://jurnalmahasiswa.unesa.ac.id/index.php/inovasi-pendidikanfisika/article/view/12289

Lin, T. C., Hsu, Y. S., Lin, S. S., Changlai, M. L., Yang, K. Y., \& Lai, T. L. (2012). A Review of Empirical Evidence on Scaffolding for Science Education. International Journal of Science and Mathematics Education, 10(2), 437-455. https://doi.org/10.1007/s10763011-9322-z

Made Rajendra, I., \& Made Sudana, I. (2018). The Influence of Interactive Multimedia Technology to Enhance Achievement Students on Practice Skills in Mechanical Technology. Journal of Physics: Conference Series. https://doi.org/10.1088/17426596/953/1/012104

Mardiana, N., \& Kuswanto, H. (2017). Android-assisted Physics Mobile Learning to Improve Senior High School Students' Divergent Thinking Skills and Physics HOTS. AIP Conference Proceedings. https://doi.org/10.1063/1.4995181

Morrison, G. S. (2012). Dasar-Dasar Pendidikan Anak Usia Dini. Indeks.

Mundilarto. (2002). Kapita Selekta Pendidikan Fisika. JICA.

Nofrion, N., \& Wijayanto, B. (2018). Learning Activities in Higher Order Thinking Skill (HOTS) Oriented Learning Context. Geosfera Indonesia, 3(2), 122-130. https://doi.org/10.19184/geosi.v3i2.8126

Nur Aini, Abdurrahman, \& Maharta, N. (2015). Pengaruh Aktivitas Scaffolding dalam Konteks Scientific Approach terhadap Hasil Belajar Konsep Kalor. Jurnal Pembelajaran Fisika, 3(3), 51-62. http://jurnal.fkip.unila.ac.id/index.php/JPF/article/view/8580

OECD. (2013). PISA 2012 Assessment and Analytical Framework: Mathematics, Reading, Science, Problem Solving and Financial Literacy. OECD Publishing.

Prastowo, A. (2014). Panduan Kreatif Membuat Bahan Ajar Inovatif. DIVA Press.

Pratama, N. S., \& Istiyono, E. (2015). Studi Pelaksanaan Pembelajaran Fisika Berbasis Higher 
Order Thinking (HOTS) pada Kelas X Di SMA Negeri Kota Yogyakarta. PROSIDING : Seminar Nasional Fisika Dan Pendidikan Fisika.

Putra, P. D. A., \& Sudarti. (2015). Real Life Video Evaluation dengan Sistem E-Learning untuk Meningkatkan Keterampilan Berpikir Kritis Mahasiswa. Jurnal Kependidikan: Penelitian Inovasi Pembelajaran, 45(1). https://doi.org/10.21831/jk.v45i1.7187

Rahayu, T., Mayasari, T., \& Huriawati, F. (2019). Pengembangan media website hybrid learning berbasis kemampuan literasi digital dalam pembelajaran fisika. Jurnal Pendidikan Fisika, 7(1), 130. https://doi.org/10.24127/jpf.v7i1.1567

Schunk, D. H. (2012). Learning Theories: An Educational Perspective. Pearson Education Inc.

Slavin, R. E. (2011). Psikologi Pendidikan: Teori dan Praktik. Terjemahan Marianto Samosir. (9th ed.). Indeks.

Srisawasdi, N., \& Sornkhatha, P. (2014). The Effect of Simulation-based Inquiry on Students' Conceptual Learning and Its Potential Applications in Mobile Learning. International Journal of Mobile Learning and Organisation, 8(1), 28-49. https://doi.org/10.1504/IJMLO.2014.059996

Sudijono, A. (2009). Pengantar Evaluasi Pendidikan. Rajawali Pers.

Suparno, P. (2013). Metodologi Pembelajaran Fisika Konstruktivistik dan Menyenangkan (edisi revisi). Universitas Sanata Dharma.

Supeno, Astutik, S., Bektiarso, S., Lesmono, A. D., \& Nuraini, L. (2019). What Can Students Show about Higher Order Thinking Skills in Physics Learning? IOP Conference Series: Earth and Environmental Science. https://doi.org/10.1088/1755-1315/243/1/012127

Thiagarajan, S., Semmel, D. S., \& Semmel, M. I. (1974). Instructional Development for Training Teachers of Exceptional Children: A Sourcebook. Center for Innovation in Teaching the Handicapped.

Toharudin, U., Hendrawati, S., \& Andrian Rustaman, H. (2011). Membangun Literasi Sains Peserta Didik. Humaniora.

Wang, J. Y., Wu, H. K., Chien, S. P., Hwang, F. W., \& Hsu, Y. S. (2015). Designing Applications for Physics Learning: Facilitating High School Students' Conceptual Understanding by Using Tablet PCs. Journal of Educational Computing Research, 51(4), 441-458. https://doi.org/10.2190/EC.51.4.d

Wartono, W., Suyudi, A., \& Batlolona, J. R. (2018). Students' Problem Solving Skills of Physics on the Gas Kinetic Theory Material. Journal of Education and Learning (EduLearn), 12(2), 319-324. https://doi.org/10.11591/edulearn.v12i2.8424

Wati, E. R. (2016). Ragam Media Pembelajaran: Visual - Audio Visual - Komputer - Power Point - Internet - Interactive Video (A. Jarot (ed.)). Kata Pena.

Woolfolk, A. (2009). Educational Psychology: Active Learning Education (bagian pertama). Terjemahan Helly Prajitno Soetjipto \& Sri Mulyantini Soetjipto. (10th ed.). Pustaka Pelajar.

Yin, C., Song, Y., Tabata, Y., Ogata, H., \& Hwang, G. J. (2013). Developing and Implementing a Framework of Participatory Simulation for Mobile Learning Using Scaffolding. Educational Technology and Society, 16(2), 137-150. https://www.jstor.org/stable/jeductechsoci.16.2.137?seq=1

Zainiyati, H. S. (2017). Pengembangan Media Pembelajaran Berbasis ICT: Konsep dan Aplikasi pada Pembelajaran Pendidikan Agama Islam. Kencana. 